\title{
A study of the woman in the crowd and her desperate courage (Mark 5:21-43)
}

\begin{abstract}
Author:
Robin Gallaher Branch ${ }^{1,2}$

\section{Affiliations:}

${ }^{1}$ Faculty of Theology, North-

West University, South Africa

${ }^{2}$ Department of Bible and

Theology, Victory University,
\end{abstract} USA

\section{Correspondence to:}

Robin Gallaher Branch

Email:

rgbranch@victory.edu

\section{Postal address:}

255 North Highland,

Memphis, Tennessee

38111, USA

Dates:

Received: 26 Jan. 2012

Accepted: 28 Aug. 2012

Published: 23 July 2013

How to cite this article: Branch, R.G., 2013, 'A study of the woman in the crowd and her desperate courage (Mark 5:21-43)', In die Skriflig/In Luce Verbi 47(1), Art. \#649, 13 pages. http://dx.doi.org/10.4102/ ids.v47i1.649

\section{Copyright:}

(C) 2013. The Authors. Licensee: AOSIS OpenJournals. This work is licensed under the Creative Commons Attribution License.

Read online:
This article examines the cameo appearance of an unnamed woman in the gospel of Mark, a member of a crowd following Jesus (Mk 5:24b-34). Chronically ill and probably dying, she thinks she is inconspicuous. The text identifies her in terms of her gender, illness, covenant status, prolonged suffering and penury. Yet, a careful reading reveals her stealth, desperation, courage and eloquence - all elements of character and, it turns out, of a faith focused on Jesus. Combining both literary and canonical insights, this article shows how the story of the anonymous woman, set within the larger context of the healing of Jairus' daughter, sheds light on the developing concepts of faith, fear, purity, discipleship, confession and family matters in Mark. The woman's interaction with Jesus adds depth to Mark's portrait of him and contributes to the ongoing revelation in Mark that Jesus is indeed the Son of God (Mk 1:1).

'n Studie van die vrou tussen die menigtes en haar desperate dapperheid (Mark 5:21-43). Hierdie artikel ondersoek die reliëfverskyning van 'n naamlose vrou in die evangelie van Markus. Sy was deel van die skare wat Jesus gevolg het (Mark 5:24b-34). Omdat sy kronies siek en moontlik sterwend was, het sy gedink sy is onopvallend in die skare. Sy word in die teks geïdentifiseer in terme van haar geslag, siekte, verbondstatus, langdurige lyding en armoedige voorkoms. 'n Noukeurige bestudering van die gedeelte openbaar ook haar heimlikheid, desperaatheid, moed en welsprekendheid - alles eienskappe van 'n sterk karakter en, soos dit later blyk, haar gefokusde geloof op Jesus. Deur die letterkundige en kanonieke insigte te kombineer, wys die artikel hoe die verhaal van die anonieme vrou, gesien teen die agtergrond van die genesing van Jaïrus se dogtertjie, lig werp op die ontwikkelende konsepte van geloof, vrees, suiwerheid, dissipelskap, belydenis en familie-aangeleenthede in die boek Markus. Die vrou se interaksie met Jesus verskaf diepte aan Markus se uitbeelding van Hom en maak ' $n$ bydrae tot Markus se deurgaanse openbaring dat Jesus inderdaad die Seun van God is (Mark 1:1).

\section{Introduction: The woman in the crowd}

I choose to call the unnamed woman introduced in Mark 5:25 the 'woman in the crowd'. ${ }^{1}$ Others call her the 'woman with the flow of blood' (Miller 2004:52) or the 'woman with the haemorrhage' (Murphy 2005:102; Williamson 1983:108-110). Although her illness debilitates her, she refuses to let it define her. This marks her as a woman of courage. The text develops this concept: she is more than her illness. Her illness, however, consumes her life, for it defines the way others treat her and think of her. Although textually nameless, one tradition calls her 'Veronica' (Lockyer 1965:194) ${ }^{2}$ and another tradition 'Bernice' (cf. Levine 2001:74). ${ }^{3}$ I wish to emphasise this: her initial condition is not her conclusion. ${ }^{4}$

Well then, what is known about her? ${ }^{5}$ Firstly, her story takes place within a larger one: the request of Jairus, a synagogue ruler (Mk 5:21-43), who asks Jesus to come immediately and lay hands on his daughter who is at the point of death (vv. 22-23). Jesus agrees, and on the way is 'interrupted' by the woman's touch (v. 27). Secondly, the text describes her in terms of her health. ${ }^{6}$

1.Tolbert (1992:267) likewise calls her the "woman in the crowd'.

2.According to tradition, Veronica wiped Jesus' face on his way to the cross (cf. Thurston \& Attwater 1956:III.82-83).

3.Eusebius (c. AD 265-339), the church historian and Bishop of Caesarea, offers insights on the woman's location, Caesarea Philippi, and on a statue depicting her healing. Eusebius (2007:238) writes of seeing 'a bronze statue of a woman on bent knee, stretching out her hands like a suppliant. Opposite to this was another of the same material, a standing figure of a man clothed in a handsome double cloak and reaching his hand out to the woman. Near his feet on the monument grew an exotic herb that climbed up to the hem of

4.Selvidge (1984:623) notes the woman's 'gynecological problems have caused her anguish, but they will not keep her cloistered from society'.

5.The interlocking stories of Jairus and the woman also appear in Matthew 9:18-26 and Luke 8:41-56. Powell (2005:70) writes that an interesting feature of the passage is that more is known about the woman and her actions than about Jesus.

6. Haber (2003:173) emphasises the link between the woman's health and purity or impurity issues. 
She is a woman with an ongoing condition, a flow of blood.? Presumably, her condition is an ongoing menstrual cycle (Miller 2004:54). ${ }^{8}$ She has endured the chronic condition for 12 years, suffered greatly under the care of many doctors, and spent all she had. Instead of getting better, her condition has worsened (vv. 25-26). ${ }^{9}$

Much is discerned from this terse depiction. ${ }^{10}$ She is a woman of the covenant: born into it and subject to it. She is a mature woman and middle-aged, and although able chronologically to have children, she is infertile. ${ }^{11}$ The text makes no mention of any attendant, neither a maid who accompanies her, nor a relative. She appears to be alone in the world. ${ }^{12}$ Although ill, she is mobile. Quite likely a resident of Capernaum, ${ }^{13}$ she becomes part of the crowd in a somewhat disguised state, in other words her clothing (because of her condition) may be layered, and she may attempt to cover her face so as not to be seen or recognised. ${ }^{14}$ Although Mark's description recounts specific details about the woman and her unsuccessful search amongst doctors for a cure, it remains silent about something every other woman who hears or reads the story realises: the woman's life is a constant routine of washing and drying rags to catch and staunch the flow of her blood. Furthermore, her condition may emit an odour. As such, it is potentially very embarrassing. Significantly, Mark's audience immediately knows the ramifications of 'an issue of blood for twelve years' (Mk 5:25): her condition excludes her from worship and community life..$^{15}$ Concerning first century life, Bouquet (1953:212) stresses the importance of congregational worship in a synagogue and the communal value of praying and responding together (author's own emphasis) that shared worship gave.

Therefore thus excluded, ${ }^{16}$ a woman with the ongoing condition of unstoppable menstrual flow would be a tremendous burden on her family. All garments, linens, utensils, and furniture she touched, sat on or used had to be washed (cf. Lv 15:25-27). Likewise, people who touched

7.Swanson (2011:271) calls it a 'river of blood', arguing its unceasing flow has washed away 'the woman's whole life'.

8. However, Levine (2001) points out that the flow could have come from the breast, nose, an unhealed wound, or another area of the body. This article acknowledges Levine's insight, but sides with the traditional view, because the woman's stealth in seeking Jesus and her calculated means of obtaining her healing are consistent with one who has an embarrassing condition.

9.Garland (2002:35) points out that her 12-year ostracism 'must have caused her physical, psychological, social, and economic suffering'.

10.Deen (1955:182-183) notes the woman is introduced as weak, weary and disheartened, but leaves in peace after her encounter with 'the greatest physician of them all'.

11.Wall (2010) links the story of the woman with the issue of blood and conditions many contemporary women in Africa face after childbirth.

12.Unlike an earlier healing in Mark, that of Simon's mother-in-law (Mk 1:30-31), the woman is not identified in terms of her male relatives.

13.Lockyer (1965:194) disagrees, saying the woman is probably a resident of Paneas or Caesarea Philippi.

14.Cotter (2001:57) sees the description as a defense for the woman's 'unfitting behavior', almost as an apology or justification for her healing.

15.That is the position of this article. However, Haber (2003) offers another view that perhaps softens the kind of life the woman arguably led. The woman may have perhaps solf safeguarded herseff from censure from the crowd by washing her hands (see LV one's hands before touching another person, utensils, or vessels means that a person will not pass on his impurity.

16.As would be a man with a flowing, seminal discharge, see Leviticus 15:25-30 her were unclean until evening. Evidently, eventually her prolonged condition seems to have led to her exclusion from her family, for the text says she had spent all her money on a worthless chase of healing from physicians who only increased her suffering (Mk 5:26).

I imagine ${ }^{17}$ her life as one without hugs from friends, children and parents, as lacking normal human contact, ${ }^{18}$ as devoid of marital rights with its duties and privileges, ${ }^{19}$ as full of toil because of the need to constantly wash everything, and as expensive because of the financial implications of a chronic illness. ${ }^{20}$ She is probably without income, because she is unemployable. ${ }^{21}$ In a culture dominated by the shame and/ or honour motif, the woman experiences embarrassment and exclusion. $^{22}$

All these factors lead to this reasonable conclusion: Mark introduces this woman as lonely, isolated, impoverished, quite likely anaemic, ${ }^{23}$ and possibly dying. Her condition appears hopeless and she is desperate. ${ }^{24}$ Most would think that she is better off dead.

Yet Mark interjects hope! This woman has heard stories of Jesus (Mk 5:27)!25 Prior to this incident, Mark records that Jesus had commanded an evil spirit to leave a man (Mk 1:2128), healed Simon's mother-in-law by taking her hand (Mk 1:30), reached out his hand and touched a leper (Mk 1:40-45), told a paralytic his sins are forgiven and commanded him to take up his mat (Mk 2:1-12), and ordered the legion of spirits in the man who lived amongst the tombs in the region of Gerasenes to leave him (Mk 5:1-20). Reading Mark's gospel in the order presented, it is reasonable to assume that the woman has heard these or other stories that present Jesus favourably. Based on this, she convinces herself that if she touches Jesus' clothes, she will be healed. ${ }^{26}$

17.Darden (2006:13), who likewise sees imagination and participation in the gospel stories, writes: 'Here's the wonderful thing - we are part of that story! We play an important role in God's Great Plan. This is our story. The Bible is our roadmap and our cast list.'

18.The woman's finances and strength are depleted, setting the stage for greater glory to be given to the Lord, Calvin (1981:411) writes.

19.Selvidge (1984:619) writes that 'sexual activity and normal social functions were prohibited during a woman's "infectious" time'.

20.'She displayed intense energy and unconquerable spirit in pursuit of health, Spurgeon (1959:70) writes.

21.For example, she could not serve in a family business or a shop that dealt with the public.

22.Wall (2010) believes the woman has what gynaecologists call menometrorrhagia:a heavy, irregular, and unpredictable series of menstrual periods. Looking at the Greek phrase, ousa en rhusei haimatos, which means 'in a state of blood flow', Wall (2010:50) says it indicates 'a steady ooze rather than a dam burst of bleeding'.

23.Powell (2005:70) gives these conditions of anaemia: energy loss, weight loss, hair loss, paleness of skin, brittle nails, heart palpitations, difficulty in breathing and joint pain, and quite likely her organs, because of her loss of blood, were not getting a sufficient amount of oxygen and blood to function optimally. According to the National Institutes of Health, heavy menstrual bleeding or other vaginal bleeding suggests that a woman is at risk for iron-deficiency anaemia (National Heart, Lung and Blood Institute 2011)

24.Powell (2005:71) likewise sees the woman as desperate because 'she dared transgress levitical legislation regarding her condition to come out in the midst of the crowd and risk contaminating many people by inadvertently touching them'.

25.Schweizer (1978:394) says she and others who received healing were attracted to lesus 'by his reputation'.

26.The popular belief of the time was that the clothes of a holy man contained miraculous powers (Garland 2002:36). Reference to a garment comes up at least three times: Mark 5:27, 28 and 30. 
She mixes inconspicuously with the crowd, awaiting Jesus' return and deliberately orchestrates an encounter with him. ${ }^{27}$ Although she thinks it will be a quick, unnoticed, one-way meeting, she soon learns that Jesus engages those who encounter him, especially one who draws power from him. ${ }^{28}$

The woman uses the crowd's noise and jostle as cover. Thus camouflaged, she becomes a crafty risk-taker. Fellow crowd members come with mixed motives: some to see a sideshow of miracles, to hear a teaching from a parable, to see a testy, feisty encounter with the Pharisees, or to enjoy a diversion from waiting around unemployed (cf. Loader 2007:1-2). In contrast, the woman plans to get close enough to touch Jesus' garment. Displaying determination and focus, this woman sets a courageous course. ${ }^{29}$

However, the woman displays selfishness by ignoring the fact that, legally, her touch makes anyone - including Jesus and those in the crowd bumping into her - unclean. Weighing the shame of being recognised by angry people, aware of the possibility of a public reprimand, knowing that people pick up stones to drive the unclean away and heedless of the harm and inconvenience she may cause crowd members and Jesus, she nonetheless approaches Jesus. In modern terminology, she stalks him in broad daylight. She decides her need trumps others' rights.

The result? Jesus commends her for her faith (Mk 5:34)! My opinion is that when the characteristics she exhibits - desperation, hope, selfishness, pushiness, courage, persistence, and self-interest - are directed at Jesus, they constitute faith. ${ }^{30}$ Jesus both defines her action and attitude as faith and acknowledges her faith as directed at him. ${ }^{31}$

\section{Mark's audience, world, authorship and purpose}

It is traditionally accepted that the author of the gospel of Mark is John Mark, the son of one of the Marys. This Mary was known for her hospitality; her house was a meeting place for believers (Acts 12:12). ${ }^{32}$ According to the tradition of the Early Church, as expressed in the Anti-Marcionite Prologue, the gospel of Mark was written in the 'regions of

27.Miller (2004:57) says the surging crowd "conveys an impression of the chaos of humanity in an age of evil'

28.Garland (2002:36) notes that what the woman chooses to do - approach a man from behind and touch his garment - is both highly irregular and sly. I like his word choice, sly, for it captures the woman's intent.

29. Haber (2003:171) acknowledges that the woman's actions may be seen 'as a covert and calculated move'. Wall (2010:51) calls the woman 'desperate to find Jesus' and believes that coming before Jesus face-to-face and asking for healing 'would have been embarrassing and ritually dangerous'.

30.Other biblical explanations of faith are Hebrews 11:1: 'Now faith is being sure of what we hope for and certain of what we do not see,' Proverbs 3:5-6: 'Trust in the Lord with all your heart and lean not on your own understanding; in all your ways acknowledge him, and he will make your paths straight,' and Romans $4: 17 \mathrm{~b}$ : believing in God 'who gives life to the dead and calls things that are not as though they were'.

31.Similarly, these characteristics do not prohibit a person from coming to Jesus by faith.

32.As a young man, Mark was guided by his cousin Barnabas: a prophet, apostle and evangelist (Branch 2007).
Italy'. ${ }^{33}$ Furthermore, Mark drew from his association with Peter and may have composed his writings as early as the AD 50s, and surely before the destruction of the Temple in Jerusalem in AD 70 (NIV Study Bible 1995:1488). However, modern scholarship differs from this traditional view.

Consider these views. Matera (1987:16) believes Mark writes to a congregation that is predominantly, but not exclusively, Gentile Christian. ${ }^{34}$ Rhoads (2004:4-5) says that Mark, although using sources like Peter, created a story world with its own autonomous integrity. ${ }^{35}$ Blount and Charles (2002:9-11) view Mark as a gospel presenting apocalyptic choices. They believe Mark saw the conflict between Judea and Rome as inevitable.

It seems to me that Mark literally shouts his purpose in verse $1 .{ }^{36}$ Absolutely and without ambiguity he asserts: 'The beginning of the gospel about Jesus Christ, the Son of God' (Mk 1:1, italics added). ${ }^{37}$ Mark dramatically heralds an event - the coming of Jesus Christ - after which history the world over is forever changed (English 1992:15). When a biblical writer makes such an editorial comment - in this case that the work is about Jesus Christ, the Son of God - the subsequent narrative sets out to prove the statement. ${ }^{38}$ In Mark, the story of the woman in the crowd adds more insight on this opening verse and contributes to proving it. Jesus both proclaims a message and challenges people to respond (English 1992:16). The woman with the issue of blood responds. But the woman needs a miracle. Luckily miracle stories abound in Mark (Mack 1988:217-218).

\section{Literary methodology and canonical insights}

This article employs a literary-critical methodology and contains canonical insights. ${ }^{39}$ Mark 5:21-43 is an intercalation:

33.Minear (1960:7) writes that in all likelihood Mark was written to the church in Rome in the middle of the first century.

34.Matera (1987:17) notes an air of expectancy in Mark's gospel; a feeling of the nearness of the apocalypse. The community members believe in the soon return of Jesus.

35.Its values include a choice, that of saving one's life or of losing it, and a chance to respond to the arrival of the Kingdom of God by responding in faith to Jesus (cf. Rhoads 2004:45-54).

36.To me, this verse is as profound as Genesis 1:1 - a verse directly opposed to prevailing creation theories in Mesopotamia.

37.Arguably from here on, Mark backs up this editorial statement that Jesus Christ is the Son of God. Subsequent verses show that Jesus excels in miracles of healing, delivering people from demons, restoring sight, speaking a withered hand into wholeness, calming both wind and wave, and raising a dead girl back to life. He wholeness, calming both wind and wave, and raising a dead girl back to life. He
forgives sin. These stories verify Mark's statement in Mark 1:1. This technique, backing up an editorial statement, is common throughout the biblical text. For example, the story featuring the wise woman of Abel Beth Maacah (2 Sm 20) example, the story featuring the wise woman of Abel Beth
shows why she is introduced as wise (cf. Branch 2009:9-17).

38.Consider two examples from the Old Testament. Proverbs 1:8 directs a son to listen to his father's instruction and not to forsake the teachings of his mother. Arguably, Proverbs can be read as an instruction book for sons. Similarly, 1 Samuel 25:2-3 gives details about a married couple named Nabal and Abigail. Nabal, a wealthy man, is surly and mean in his dealings, and his wife Abigail is both intelligent and beautiful. The story that follows backs up these editorial assertions (cf. Branch 2009:9-17).

39.In a canonical approach, the text is looked at in its final (i.e. canonical) form. The community of faith to which it is addressed or under whose aegis it took shape is recognised (cf. Hill \& Walton 2000:575). The Westminster Confession of Faith (Pratt 2003:I.6) uses this pivotal insight: 'The whole counsel of God concerning all things necessary for His own glory, man's salvation, faith and life, is either expressly set necessary for His own glory, man's salvation, faith and life, is either expressly set
down in Scripture, or by good and necessary consequence may be deduced from down in Scripture, or by
Scripture' (italics added). 
a second story interrupts the first and is sandwiched between the beginning and the end of the first story. ${ }^{40}$ Mark, a marvellous storyteller, ${ }^{41}$ likes intercalations and employs them frequently. ${ }^{42}$

When reading biblical narration in both testaments, general literary rules apply. ${ }^{43}$ For example, a story in the biblical text has a beginning, middle and end. Standard story elements are character, central idea or plot, conflict, setting, tone, point of view and language. ${ }^{44}$ In Mark, and throughout scripture, each story fits into the overall purpose of the biblical writer and into a book's themes. ${ }^{45}$ Jesus is presented as a miracle worker in Mark; someone more powerful than disease, death and natural elements like wind and storm. The stories of Jairus and the woman contain insights on the developing Marcan themes of purity, faith, fear, discipleship, confession and family matters.

In a literary sense, the woman and Jairus both grow and develop as characters, in other words, they change. They are dynamic as opposed to static characters (Lostracco \& Wilkerson 2008:14-15). The woman shows courage, because she makes a full confession when discovered (Mk 5:33), and Jairus expresses astonishment when his daughter suddenly lives again (Mk 5:42). These details make them realistic, believable characters. (Lostracco \& Wilkerson ibid:12). Gaiser (2010:8) correctly says that 'both stories involve unexpected twists that take the participants beyond what they anticipated in their initial approach to Jesus'.

The larger pericope's (Mk 5:21-43) central idea is that Jesus is a miracle worker who loses power ${ }^{46}$ (when touched by a woman with faith in v. 30) and displays authority and power over death (when he takes the dead girl by the hand and commands her to rise in vv. 41-42). A central idea carries with it a plot, and a plot involves a conflict. Conflict, a significant literary tool drawn from the plot or central idea, occurs when opposing forces collide (Lostracco \& Wilkerson 2008:19). Jesus 'collides' with a chronic illness and death in the two conflicts in the two intercalated stories. ${ }^{47}$ Jesus not only tackles them head on, he also confronts death by grasping the child's hand before speaking to her (Swanson 2011:278).

40.Scholars wonder if Mark combined two independent stories or if they occurred together. Guelich (1989) notes Mark's tendency for intercalation stories and sits on the fence on whether or not they are independent stories. He (Guelich ibid:292) states that most scholars assign the stories to a collection of miracle stories Mark found and used. I believe they occur together.

41.Robbins (1973:224) commends 'Mark's ability to create vivid narrative'.

42.For other examples of 'sandwiching' in Mark, see Mark 3:22-30; 6:7-30; 11:12 25; 13:5-27; 14:1-11; 14:18-25; 14:53-72 (Boring \& Craddock 2004:112). The interlocking miracles represent the pressure under which Jesus worked (Hiebert 1979:125).

43.See Branch (2009:9-17) for a fuller description of biblical narrative.

44.See Lostracco \& Wilkerson (2008) for an excellent and concise explanation of the short story.

45.Mark 5:21-43 smacks of an eyewitness account (Mann 1986:282). It feels real. Mann (ibid:284) supports this view by citing the woman's fear and the impatient reaction of the disciples as believable emotions.

46.Swanson (2011:274-275) notes that the word used for power also refers to sexual potency. He (Swanson ibid:275) adds that 'any ancient audience would have caught the double meaning in this scene and would have understood, physically, the way male bodies got nervous around menstruating bodies'.

47.Reading canonically, Hebrews 2:14-15 clearly shows death as an enemy
The action in the stories is a set of events that constitute a plot. The events have a cause-and-effect relationship that leads to some kind of resolution of the conflict (Lostracco \& Wilkerson 2008:19, 21). As Schweizer (1978:399) notes, ultimately these Marcan stories show that 'conflict brings Jesus to the cross'. The stories of the woman in the crowd and the resuscitation of Jairus' daughter establish Jesus, like Elijah before him, as (at the very least) a mighty Prophet whose God is stronger than chronic illness and death (cf. Branch 2009:125-130; Branch 2003).

Jesus sets the pericope's favourable tone by immediately going with Jairus. The narrative's tone, another literary element, is favourable and even sympathetic to the woman and Jairus. The text records the woman has suffered, pascho, under many doctors (Mk 5:25). In contrast, the narrative seems to portray an unfavourable tone toward the disciples when they question Jesus when he asks who touched him, toward the messengers who come to Jairus abruptly announcing the death of his daughter, and toward the mourners wailing over the girl's death (Mk 5:31, 35, 39; cf. Lostracco \& Wilkerson 2008:50).

Tone and language often overlap. The text introduces Jairus (Mk 5:22) with the Greek word idou. In the imperative, its meaning is behold, lo or see. In using this commanding word, Mark employs a textual maker common in the Hebrew Bible - it represents emphasis. ${ }^{48}$

A setting can be either general or specific. The setting and time are 'the where' and 'the when' of events (Lostracco \& Wilkerson 2008:31). In the stories of Jairus and the woman, the setting, a seaside town, is specific. The time is daytime. The story begins on the western shore of the Sea of Galilee, and people mill around. ${ }^{49}$ Jesus and his disciples arrive by boat from the eastern side. ${ }^{50}$ The setting begins outside, on the waterfront, and in public. It progresses along a narrow city thoroughfare to Jairus' house and concludes in the room of the dead girl.

The story opens with 'extras', a significant number of people lingering to meet Jesus, enough to indicate he was regarded as a significant attraction (Mk 5:21; Wuest 1966:108). The word epi indicates that people gathered after him and not so much to him. In other words, the people did not gather themselves, but 'were controlled by the irresistible longing to see Jesus and avail themselves of His help' (Wuest ibid:108).

The point of view in the stories is the third person. The narrator does not use the pronouns $I$ or me (Lostracco \&

48.For example, the word Behold! is one textual marker that alerts hearers and readers to pay attention. Another emphasis technique is repetition (Lostracco \& Wilkerson 2008:40). In this pericope, note the double use of the word twelve (Mark 5:25, 42).

49.Loader (2007:3) picks up on the resentment present in Capernaum: the unemployment, the desperation of men to feed their families, the women who possibly turned to prostitution as a means of survival. Any help available circulated within the orbit of the synagogue and relied on donations (Loader ibid:3). Many people, perhaps including the unnamed woman, fell through the cracks.

50.Jesus and his disciples are returning from the country of the Gerasenes where Jesus healed a man named Legion of - probably literally - a legion of demons. Jesus has commanded him to go back to his home and people and to tell - render tidings, from apaggello - his own family what really happened to him (cf. Wuest 1966:107). 
Wilkerson 2008:25). As is common in biblical narration, the narrator does not divulge the thoughts of Jairus or Jesus. However, the narrator states the woman's repetitive thought ('If I just touch his clothes, I will be healed') that must have been based on her public confession (Mk 5:28, 33). ${ }^{51}$

I see an irony as well and a sense of a possible difference of opinion amongst the characters in the Jairus story. Jairus refers to his 'little daughter' and Jesus commands the 'little girl' to get up (vv. 22,41). However, the daughter, at age 12, may disagree! She may think of herself as almost ready to be married $!^{52}$

Significantly, Mark's stories convey urgency. This is true of the stories of Jairus and the woman. One literary way Mark fosters, is through the word immediately. The Greek words eutheos and euthus, translated immediately, occur 17 times in Mark. $^{53}$

\section{'When she heard about Jesus' (Mark 5:27a)}

It is significant that the woman had heard about Jesus (v. 27). The definite article before the name Jesus in verse 27 indicates there was a specific Jesus amongst many of that name of whom she had heard (Wuest 1966:109). What had she heard ${ }^{54}$ Mark seems to indicate she had heard the earlier stories in his narrative. According to this view, her own story (because it occurred in public) is then heard by others who appear later in Mark's gospel, like the Geresene townspeople (Mk 6:53-56) and Bartimaeus (Mk 10:46-52).

If the stories that the woman has heard are in a chronological order in Mark and the woman has heard them, she is still left with her predicament..$^{55}$ No story so far exactly fits her situation. ${ }^{56}$ After all, Jesus touched people, he commanded various healings, he faced people, he controlled his power, he channelled his power at will. Her embarrassing condition, she may have reasoned, precludes her from approaching him publicly. Based on her confession, she seems to have wondered: 'Is the reverse possible? Can I touch his clothes from behind and be healed?' What she heard, arguably,

51.Mark 5:28 ('for she thought/said') is in the imperfect and means that she kept on saying over and over to herself or saying to others (Wuest 1966:110). The woman keeps saying or thinking: 'I shall be whole and/or I shall be saved'. The Greek verb, sozo, for the word whole or saved, here means being saved both from a physically ill condition and from a spiritually evil state (Wuest ibid:110).

52.See Miller (2004:55). Although the Bible lacks 'clear evidence for the age at which an Israelite man or woman married or entered households', it is likely that the 'were involved in married, sexually active family life in their mid-teens' (cf. ed. Freedman, Myers \& Beck 2000:862).

53.Mark 1:12, 28, 31, 42; 2:8, 12; 4:5, 15, 16, 17, 29; 5:2, 30; 6:27, 50; 10:52; 14:43

54.A canonical reading sheds light on the significance of the woman's hearing of Jesus: what she heard led to faith. The apostle Paul writes that 'faith comes by hearing and hearing by the word of God' (Rm 10:17; cf. Boring \& Craddock 2004:494).

55.The stories smack of miracles. They tell of Jesus' power over wind and waves, demons, paralysis and fever. The restoration of a withered hand is a miracle of recreation. In terms of relationships, Jesus institutes a new kind of family based on obedience to God; he is its focal point.

56. Reading canonically, another story in another gospel perhaps offers the woman in the crowd hope beforehand, or confirms her action afterward. In Luke 7:36-50, another unnamed woman touches Jesus and receives forgiveness for her sins. convinced her that she could touch his clothes from behind and that she would be healed. ${ }^{57}$

\section{Blood: The central issue concerning the woman in the crowd}

In the Marcan story of the woman in the crowd, the literary conflict concerns not a moral issue of a sexual nature, but the impurity her chronic bleeding condition presents. Hers is not a promiscuous sexual situation, but a gender issue. ${ }^{58} \mathrm{Her}$ flow of blood, whilst not contagious, nonetheless necessitates her separation from others. Leviticus 15:25-30 is clear. ${ }^{59}$ Her action, in what Swanson (2011:274) likens to 'swimming through the crowd', brings all she touches 'into contact with blood' ${ }^{60}$ Scripture links blood and life. Wenham (2003:94) writes that the 'underlying rational seems to be that to lose a life-liquid, such as blood, meant that the person who was suffering was under the shadow of death and therefore unfit to approach the God of life' ${ }^{61}$

The woman has what is called zob in Hebrew, a chronic discharge. ${ }^{62}$ Menstruation is not a chronic disease unless it lasts longer than a normal time of seven days. The woman has been bleeding for 4380 days. Over twelve years, a normal time of a woman's period measures 1008 days (7 days x 12 months $x 12$ years). In other words, her days of prolonged flow numbered $3372 .{ }^{63}$

Undoubtedly she lacks energy. The text indicates her consultation of doctors left her more infirm. ${ }^{64}$ There is no financial, physical, or family hope - and she knows it.

57.0 sborn (1981:34) argues that healing and salvation are interchangeable in terms of God's will. Consider these counter arguments he makes about healing and be aware of his facetious tone: 'Maybe it isn't God's will to save you or heal you', 'Perhaps your sin/illness is for God's glory'; 'Perhaps God is using this illness and/or your sin to chastise you'; 'Be patient and wait in your sin or illness until God chooses and wills to save you or heal you'. 'Clearly the time of miracles and conversion is past.' Luckily, the actions of this desperate woman show she did not conversion is past'

58.Josephus (2007:V.227) writes that those with gonorrhea and leprosy were banished and excluded to areas outside the city. They were 'shut out of the temple', Josephus
(ibid:V.227) says. Menstruating women were not permitted in the Temple. (ibid:V.227) says. Menstruating women were not permitted in the Temple.
Furthermore, even when their period finished, they were allowed only to go to a restricted section of the Temple. Men who were not thoroughly pure could not go into the inner court of the Temple; even priests who were not pure were excluded from this inner court (Josephus ibid:V.227). Consequently, the woman's action of touching Jesus technically excluded him from going to the Temple's inner court.

59.Leviticus 15 addresses maladies. Its goal is restoration of fellowship, both horisontally in community and vertically in communion with God. A reason for the purity regulations in Leviticus 15 is the general health of the population and the holiness of worship (Sherwood 2002:69-70). Leviticus 15:31 offers a reason for the commands regarding both men and women with discharges: 'You must keep the Israelites separate from things that make them unclean, so they will not die in their uncleanness for defiling my dwelling place which is amongst them' (v. 31).

60.Swanson (2011:274) notes what may have been a prevalent belief at the time: a menstruating woman, if she touches a man, can make him impotent.

61.Likewise, semen is a life liquid.

62.Leviticus 15:25 mentions a discharge of blood outside of menstruation and defines its time of uncleanness as equal to the length of time for the discharge (Van Gemeren 1997:I.1087).

63.The Talmud addresses the woman's condition with 11 remedies (Barclay 1956:128), indicating a common malady. The Talmud recommends tonics and astringents and carrying the ashes of an ostrich egg in a linen rag in the summer and in a cotton rag in the winter (Olgivie 1975:104). Another cure was to carry a barley corn, which had been found in the dung of a she-ass. Barclay (ibid:128) believes Mark's remarks represent jibes at doctors.

64. Evidently there were professional physicians during biblical times 'but their work was largely considered to be magical' (Packer \& Tenney 1980:464). 
The Leviticus text says that anything or any person that a woman or a man with a discharge touches is unclean. ${ }^{65}$ Yet this woman's touch does not make Jesus unclean. That must have puzzled a lot of people. ${ }^{66}$

\section{Developing themes in Mark}

The woman's cameo appearance sheds light on some developing themes in Mark.

\section{Fear}

In addition to the importance of blood (Mk 5:25-29), aspects of fear and trembling are part of this pericope (Mk 5:33, 36). The woman exhibits fear when Jesus stops the crowd and 'looks for her who had touched him'. Not letting Jairus say one word when he hears his daughter is dead, Jesus commands him not to fear. Earlier in Mark, the Gerasenes townsfolk express fear when the deranged demoniac becomes a normal, clothed person. ${ }^{67}$ The disciples express fear after the wind and waves obey Jesus (Mk 4:41). Later in Mark, the religious leaders exhibit fear toward Jesus and the crowd. ${ }^{68}$

The biblical text presents fear as both a response to something new and an encounter with some aspect of the divine (Minor 2001:79). Instead of fearing the violent storm and an imminent death by drowning, the disciples fear after the wind and waves cease. Their terror occurs when they later talk amongst themselves about Jesus' action of commanding the wind and the waves to be quiet (Mk 4:41a). Similarly, the woman fears after she is healed (Mk 4:31; 5:33).

Fear comes because God's power suddenly confronts ordinary people. 'God's near presence is fearful because God's Light and Truth expose us,' Minor (2001:86) explains. The woman may fear exposure and its resulting ridicule and ostracism. She also may fear Jesus' rebuke. Jairus fears the loss of the daughter he obviously loves. The leaders of Judea fear the loss of their position and the further ruin of their country by the Romans. Arguably, the townspeople of Gerasenes fear healing and its results, for they are used to adjusting to a demoniac, but do not know how to deal with someone now dressed and in his right mind (Mk 5:14-18). Their reaction? They expel Jesus.

65.Leviticus dwells on seven forms of ritual purification and their significance for the communal health of the community. The seven are as follows:post childbirth (Lv12); leprosy (Lv 13); venereal disease (Lv 15:12-15); the male sexual function (Lv 15:16-18); menstruation and excessive menstruation (Lv 15:19-30); dead bodies (Lv 21:1-3).

66.Schnittjer (2006) provides insights on purity. He (Schnittjer ibid:294) sees the word purity in a broad sense that encompasses the ideas of holy and clean. The opposite of purity is pollution, sinfulness and profaneness. The sense in Leviticus, he writes, is that the people, community, an individual and the dwellings must be pure because 'God's glory took up residence' within a dwelling and made it sacred. To me, the actions of Jesus throughout Mark regarding touching those whom the community regards as unclean or impure, like this woman and the dead girl, show his divinity: they serve as evidence backing up Mark 1:1. Elsewhere, Jesus brings up the idea of sin by asking his accusers: 'Can any of you prove me guilty of sin?' (Jn the idea of sin by asking his accusers. 'Can any of you prove me guilty of $\sin$ ?' (Jn possessed, but they do not accuse him with the word unclean (Jn 8:48).

67.The fearful Gerasenes, recognising a power beyond human control, ask Jesus to leave (Mk 5:17). Courteous as always, Jesus departs.

68.Mark 11:15-17, 32; 12:12
Yes in Mark, those faced with the power of Jesus respond with fear. ${ }^{69}$ Similarly, this response is seen in other stories of angelic visitations, like Gabriel's visits to Daniel (Dn 10:18) and Zechariah (Lk 1:13). Minor (2001:78) puts it this way: Mark's stories 'keep telling us of the fear of God's presence that comes naturally to us human beings'.

\section{Confession}

Discovered, the woman separates herself from the crowd, comes forward, falls at Jesus' feet, and confesses (v. 33). With words tumbling forth, she tells him 'the whole truth' (Mk $5: 33 \mathrm{~b}){ }^{70}$ She gives Jesus and all listening details about her condition and details about her efforts to become well again. The woman, as one who has just experienced the power of God to heal, evidently lets feelings, fears and joys, bubble out in no particular order. ${ }^{71}$ Her halting confession is like the expression of amazement and joy rendered by the widow of Zarephath when Elijah places her suddenly alive son in her arms (1 Ki 17:24). There, the Hebrew is disjointed, full of sentence fragments - and thoroughly believable (Branch 2003:300-303). Amazement, awe, fear and gratefulness are emotions erupting all at once when a person sees or experiences the power of God. Honest human emotions enable the stories to smack of realism - and for the story's characters to be believable.

Jesus, a keen listener, makes confession easy. ${ }^{72}$ Evidently, the woman did not simply give a generalised version of the truth or attempt to shield herself from public shame. ${ }^{73}$ In response to what must have been a specific and potentially humiliating rendition, she receives honour and restoration without censure. ${ }^{74}$ Jesus frees her from any pattern of selfcondemnation. ${ }^{75}$

Reading canonically, confession in the Old Testament occurs most frequently on national and congregational levels: ${ }^{76}$ Moses (Ex 33:12-17), Solomon (1 Ki 8:22-61) and Daniel (Dn

69. Hedrick (2007:302-303) notes that amazement is registered when the paralytic is healed (Mk 2:1-12), when Jairus' daughter is brought to health from a comatose or dead condition (Mk 5:35-43), and when the deaf man with a speech impediment is healed (Mk 7:31-37). However, no amazement is recorded for these healings: Peter's mother-in-law (Mk 1:29-31), a leper (Mk 1:40-45), the man with a withered hand (Mk 3:1-6), the woman of the issue of blood (Mk 5:34), a blind man (Mk 8:22-26), and blind Bartimaeus (Mk 10:46-52). From a literary perspective, the different reactions smack of realism and an eyewitness perspective.

70.The woman told the whole truth: pason ten aletheian (Wuest 1966:113).

71.Deen (1955:182-183) describes the healing in this way: 'It was like the turning on of a great light in a dark room. She felt His healing energy go through her body immediately, and He too sensed that power had gone from Him.'

72.Foster (1998:145) writes that the discipline of confession is difficult 'because we all too often view the believing community as a fellowship of saints before we see it as a fellowship of sinners'.

73.Perhaps the woman is initially ashamed, because she has violated the law (Cotter 2001:58). Yet the passage makes no mention of shyness, shame or honour. The woman's fearfulness may be explained, because she was outside the cultural norms of home, compound and family; she definitely seems to be unescorted. The ideal woman in the Greco-Roman world was expected to be at home with her family, and to be shy, modest and quiet, Cotter (ibid:58) writes.

74.In a contemporary context, her confession may show inner healing (cf. Foster 1998:151).

75.Foster (1998:153) says this in his chapter on the discipline of confession.

76.One individual confession comes from David. See 2 Samuel 12, especially verses 13-23, as well as Psalm 51. 
9:4-19) intercede for the people and nation. ${ }^{77}$ On the whole, the New Testament defines confession more narrowly, linking it with faith and focusing confession and faith on Jesus (cf. Mk 9:24; Rm 10:9). Proverbs 28:13 states that the person who conceals a sin does not prosper, but the one who confesses and renounces sins, finds mercy. The woman certainly confessed and received much mercy. Confession enables a person to live a truthful, open life. The woman's desperation leads to a confession. Her action of telling the truth leads to a change in her circumstances and to her reacceptance into the community, and being restored to the covenant community leads to her being part of a new family, one centred on her healer. ${ }^{78}$

\section{Purity}

Whilst a thorough analysis of purity in the gospel of Mark is outside the scope of this article, a few observations can apply. The system of purity for the Hebrews (and later for the Israelites) was unique amongst the ancients for it avoided the magic practices of their neighbours, like the Canaanites (and later the Romans), and allowed for an examination of disease from a practical and empirical standpoint (Miller \& Miller 1978:72). It became the way the Jews formed themselves into classes (Mathew 2000:102). It emphasised the difference between God and mortal beings (Gane 2009:304). The purity system, reinforced by the Law and Temple, controlled the social identities, boundaries and classes of the Jews (Mathew ibid:102).

Arguably, a very interesting fact about Jesus so far in Mark is that, no matter if he touches an ill or diseased person or been touched by one, or extends his hand to a dead girl as he commands her to arise, or fraternises with one whose home is tombs, ${ }^{79}$ he is not made unclean. Garland (1996:55) finds the answer in the 'divine dimension in the prologue' that provides verification to Jesus' new teaching (Mk 1:27), many miracles and wisdom (Mk 6:2), and authority over sin and natural elements (Mk 2:7; 4:41; 11:28). The prologue attests that Jesus Christ is the Son of God (Mk 1:1) and progresses to his account of Jesus' baptism (Mk 1:9-11): When Jesus comes up out of the water, the heaven is torn open and the Spirit descends on him like a dove. A voice from heaven declares: 'You are my Son, whom I love; with you I am well pleased'. Jesus is set apart at baptism and marked as the Holy One of God (Mk 1:10, 24; cf. Rhoads 2004:159). As the Holy One of God, he cannot be unclean. Put another way, Jesus leaks power, indeed a positive healing power, and this leakage of power attests to his concealed identity as the Holy One of God (cf. Moss 2010:508). Through the subsequent stories, Mark provides evidence for these verses. Throughout Mark, Jesus comes and goes from the Temple unchallenged; others certainly consider him clean. Mark does not link Jesus and

77.Confession served to reinforce and reaffirm covenant membership and thereby proved essential in public worship (cf. Dt 6:4-9; ed. Freedman et al. 2000:274).

78.Put succinctly, honesty leads to confession, confession leads to change, and change leads to freedom. See Foster (1998:157) for additional insights.

79.Garland (2002:33) brings out the interesting point that the demoniac (Mk 5:1-20) lived in a place associated with uncleanness - the tombs were known as haunt for unclean spirits. uncleanness. Instead Mark lets the evidence of wholeness, life and restoration speak.

Mathew (2000:104) writes that the cultically impure, like the leper in Mark 1:40-45 and arguably like the ill woman and dead girl in this article, are made pure, because Jesus spreads purity with his presence 'and turns impurity into purity'. When Jesus encounters impurity, he amazingly reverses it. Unexpectedly, the touch of another, or Jesus' actions of touching a leper or a dead girl, not only do not make Jesus unclean, but also make the leprous clean and the dead girl alive (Mathew ibid:102)! Mathew (ibid:106) asserts that Mark's presentation of Jesus shows Jesus' 'disapproval of the purity system, which became detrimental to the interests of the poor and marginalised'. The woman in this story certainly experienced exclusion.

Jesus re-orients the concept of covenant and community purity around himself. Via his ministry and person, Jesus challenges exclusion laws by touching a leper (Mk 1:40-45). He heals Simon's mother-in-law and allows her to minister to him and with him (1:31). He enjoys the company of tax collectors and sinners and embraces them (Mk 2:15-17). His astounding claims include his ability to go directly to God in order to forgive sin (Mk 2:5). Suddenly, God's power is available to Gentiles (Mk 5:1-20; cf. Gn 12:1-3.). In short, God's community, as communicated by Jesus of Nazareth in the gospel of Mark, breaks down boundaries between people - men versus women, Gentiles versus Jews, rich versus poor, ill versus healthy, pure versus impure, living versus dead and adults versus children (Blount \& Charles 2002:10).

In his commentary on Leviticus, Ross links the Levitical laws and the Mark passage. He (Ross 2002) writes that in the encounter with the woman, Jesus did not become defiled, because Jesus is:

... the Holy One of Israel ... He made others whole. And so in this account the woman became pure. In him God had drawn near to all who had been separated. The law said that such physical diseases and bodily functions indicated that the person was earthbound and ritually unclean. The only way that they could enter the presence of God (typified by the shrine) was to be purified and then atoned for by sacrificial blood. All these laws revealing how sin and sickness separate people from God were part of the fuller revelation leading up to Jesus. The Gospel account, then, shows that Jesus both purified the woman and made the atoning sacrifice. He is God's complete remedy for humankind's complete ruin and disorder. In Christ everyone can find acceptance in the presence of the holy God. (p. 309)

Jesus makes people like this woman whole. The intercalated stories of the healing of the woman and the restoration of life to Jairus' daughter show the restoration of these two females to the larger community. Each has been given new life. Each is now clean. Their conditions of chronic illness and death are reversed. Others in the community can now interact with them in a normal way. Just as Jesus is not overpowered earlier in chapter 5 by the demons in the demoniac or by the wind and the waves in chapter 4 , but proves the stronger in both situations, he is not overpowered by a chronic illness or 
death in the conclusion of chapter 5. So far in Mark's gospel, he is stronger than any force he encounters. I believe that the proofs of Jesus' ability to remain clean are that the woman is healed and Jairus' daughter receives life. Touching the dead and being touched by someone unclean, do not make him so. Jesus rises above normal uncleanness - sort of absorbs or changes or nullifies any evidence - and thereby offers one more proof of his deity. Jesus removes any evidence of uncleanness. In this pericope, it is interesting that Jesus travels from a so-called lesser impurity, contact with a menstruant woman, to contact with a dead girl (cf. Mathew 2000:102). Garland (1996:221) writes that Jesus never avoided ceremonial uncleanness, because he knew his power could both overcome and reverse it. Throughout his morning's interaction with Jairus, the woman and Jairus' family, Jesus displays an unswerving self-confidence.

\section{Family}

Just as Jesus redirects the concept of purity toward himself, he does the same with the concept of family. Boring and Craddock (2004:120) note that a common theme in Mark is that of being on the inside or outside. Jesus redefines outsider and insider in terms of a relationship to and with him. Jesus sets himself as the new standard for evaluating relationships. He is the hub. Jesus reorders relationships within the covenant community, basing them on himself and on obedience to God (Mk 3:31-35). ${ }^{80}$

In his encounter with the woman, Jesus sets the tone by looking in the crowd for her. After hearing her confession, he encourages her by calling her by an endearment, 'Daughter' (Thugater). ${ }^{81}$ In the verse, 'Daughter, thy faith hath made thee whole' (Mk 5:33), Jesus uses the word sozo to indicate both a physical healing and spiritual restoration. He then literally tells her to 'Go into eis [peace]'. In this way, he commands her much the same way he commanded the demoniac to 'go back home to your own people' (Mk 5:19). Jesus tailors his commands in two ways. To some he says: 'Follow me.' Others, like the demoniac and this woman, he sends back to family and community.

The amazing and amazingly short encounter of Jesus and the woman re-orients the woman's life. Jesus not only places her in a new family, one centred around him, but also

80.Mary and Jesus' brothers are portrayed negatively (Boring \& Craddock 2004:120) but not so the woman in the crowd. Barclay (1956:77-79) elaborates on four aspects of kinship from Mark 3:31-35. He writes that true kinship starts with common experience. Truly, the woman in the crowd and Jesus share the experience of her healing. True kinship involves a common interest. As Barclay (ibid:79) puts it: of her healing. True kinship involves a common interest. As Barclay (ibid:79) puts it: 'All Christians are people who desire to know more about Jesus Christ.' The woman certainly knows Jesus in a personal way, because he met her at her point of need she becomes an example for others to know him too. Thirdly, true kinship shows (he will of God by actively seeking healing and touching him. True kinship incorporates a common goal. Barclay (ibid:79) states this goal is to know Christ and bring others into his kingdom. In her healing, the woman with the issue of blood clearly came to know Jesus in a deeper way and the proclamation of her healing clearly proclaimed his kingdom.

81.In a canonical sense, the concept of daughter is usually presented favourably. Here are some examples:

Joel 2:28: 'Your sons and daughters will prophesy.'

Song 2:7: 'Daughters of Jerusalem, I charge you.'

Isaiah 62:11: 'Say to the Daughter of Jerusalem, "See your Saviour comes."' honours her with an endearment, Daughter. ${ }^{82}$ Significantly, this woman is the only woman in the Bible to seek healing for herself and the only woman whom Jesus calls Daughter..$^{83}$ Surprisingly, he never asks her name, nor does she give it. Jesus and the woman are both adults and perhaps near the same age. But, as is typical of his relationships, Jesus assumes the role of the elder. He esteems her by showing all nearby that she is his true kin. She becomes the first example in Mark since his encounter with his family (Mk 3:31-35) of his power to re-order families. Her designation as Daughter covers her in a protective mantle. ${ }^{84}$ It is as if his name and character will protect her as she re-enters society.

Jesus' dismissal of her indicates that she can now enjoy the peace coming from a relationship with him (Powell 2005:74). His kind benediction ('Go in peace') confirms 'that her healing is not merely a temporary remission' (Powell ibid:74). Jesus calls her to live her faith (Schweizer 1978:395).

In Mark, Jesus presents an invitation to form a new covenant, one based on belief in him. He re-aligns family relationships around himself and defines family as whoever does God's will (Mk 3:31-35). The woman in the crowd with the chronic bleeding condition accepts. She becomes part of this new, rearranged Israel. Obeying the will of God means 'listening to Jesus, accepting his teaching, and cooperating with his mission', Ahearne-Kroll (2001:14) writes. A person's response to these demands determines if the person is on the inside and part of Jesus' new family order. Resistance to this new order means that Jesus distances himself from the person or group (Ahearne-Kross ibid:15). Reading canonically, Mark indicates that Jesus immediately leaves for Nazareth and experiences rejection from his family and townspeople (Mk 6:1-6).

\section{Faith}

The healing stories of the woman and Jairus' daughter show a crucial element of Marcan Christology, because, within them, Jesus is declared to be the Son of God (Robbins 1973:242). The interlocking stories of Jairus and the woman show that Jesus responds twice with alacrity to a cry for help and a desperate action. He calls the woman's desperate action faith. Arguably, Jairus, by coming to Jesus, exhibits faith. Jesus acknowledges faith, whether coming from a man or woman, from the rich or poor. Significantly, the woman had heard stories of Jesus (Mk 5:27). The act of hearing does not generate faith. Instead, faith is generated by the content of what is heard (Boring \& Craddock 2004:494).

Whilst faith in both testaments involves a human being, and God initiates that person's faith, faith in the New Testament becomes faith in Jesus Christ (Hay 1973:18). Because faith is understood as a gift from God, it takes an important position

82.For Matthews (1998:276) this means relationship. Jesus' use of the word obliterates the woman's isolation and gives her a new set of relationships.

83.The word Daughter sets her in a new family, which he heads. Furthermore, the endearment is non-erotic, yet allows for an expressive tenderness (Cotter 2001:59). Jesus acknowledges the intimate, personal nature of her need and of the healing she received through her faith. Similarly, Boaz called Ruth daughter and offered her protection (Rt 2:8).

84.The apostle Paul also calls Onesimus a son (Phlm 10). 
in Mark (Schweizer 1978:395). It is possible to distinguish (cf. Hay ibid:17) between a psychological faith ('trust or confidence in the person of the healer, Jesus of Nazareth') and a theological faith ('a positive relationship to God through Jesus'). Quite likely, the woman had a theological faith, because she found and received a miracle.

Significantly, Jesus calls the action, attitude and confession of the woman faith, thereby naming what she has done and acknowledging the character traits behind it. There is no textual evidence that the woman's musings that led up to her action of touching Jesus' cloak included the word faith. Instead, after hearing her confession, Jesus summarises what has happened and been said, and calls it faith. Faith focused on Jesus is a developing concept at this point. Schweizer (1978:395) states this profound insight well: 'The woman healed of her hemorrhage has to come forward with fear and trembling before she can realise that what she has done is an act of faith.'

Mark's miracle stories showcase ordinary people who are challenged to respond to a new concept: faith in Jesus as the Son of God. They tell of people who 'struggle in some way and strive in varying degrees to believe in God's restorative power amid a besieged and faithless generation' (Spencer 2010:423).

The Westminster Confession of Faith (Pratt 2003:XIV.3) observes that faith is different in degrees, weak or strong, and may be assailed and weakened, but does get the victory. The woman certainly shows a strong faith and receives a victory: healing. However, self-centredness is always part of faith. Consider Psalm 116:1a 'I love the Lord'. Verse 1b answers why: 'for he heard my voice'. The woman exhibits what I would call a messy faith, but she exercises it with such a courageous pushiness that others throughout the centuries have recognised the prominence of her story and accorded her admiration.

\section{Discipleship}

In Mark, following Jesus frequently, equals discipleship (Johnson 1978:203) ${ }^{85}$ It turns out there is more than one way to follow Jesus. The disciples follow him from place to place. But, as Johnson (1978:200) writes: 'The disciples display a basic lack of confidence in Jesus and a failure to identify him properly - they must understand that the Jesus who calms the storm at sea also quells the turmoil in human hearts.'

In contrast, the demoniac and the woman follow what Jesus says by obeying him and going back to their homes. I believe their obedience signifies that they became his followers. Ironically, the demoniac and the woman are more favourably portrayed than are the persistently blind twelve. In contrast to the disciples (Johnson 1978:202), the woman's act of following Jesus indicates she is a disciple who sees, at least in part, who he is.

85.Peacock (1978:555) says a central Marcan theme is discipleship.
Discipleship is a call to a radically new life (Peacock 1978:562). Miracles, like those experienced by the woman and the demoniac, lead to the person's new life as a disciple of Jesus (cf. Betz 1978:75). Jesus immediately takes new recruits like the healed woman and demoniac. Consider these Marcan aspects of discipleship:

- Discipleship demands a response, entails a radical break with the past, involves a personal decision and may involve suffering (Peacock ibid:561-563).

- Discipleship gradually points to the cross (Achtemeier 1978:136).

The woman certainly is set free from her past life of exclusion and embraces a new life. Like the woman, Jairus exhibits a faith in Jesus by trusting in the midst of hopelessness, Garland (1996:222) observes. In their cameo appearances, both respond to Jesus and therefore exhibit aspects of discipleship. ${ }^{86}$

\section{What the interlocking stories reveal about the developing portrait of Jesus in Mark}

The stories of the healing of the woman in the crowd and the raising of Jairus' daughter demonstrate aspects of Jesus' character. From a literary standpoint, Jesus is a wellrounded character. The stories add depth to his character, for they indicate his calmness, confidence and openness. ${ }^{88}$ In contrast to the woman's stealth, he is open; in contrast to Jairus' desperation, he is calm. Jesus refuses to mirror the emotions prevalent at the moment - fear, unbelief, anxiety and rudeness - unless that emotion is joy. Arguably, Jesus expresses joy with the woman when she tells of her healing and shares the joy of the amazed parents that their beloved daughter now lives.

Both stories show the self-giving nature of Jesus, a strong trait. He willingly deals with the two emergencies he faces after his voyage. ${ }^{89}$ Furthermore, the text indicates the possibility that Jesus was exhausted when he reached Capernaum. Recently, Jesus had been so tired that he slept through a perilous storm and was awakened by his disciples (Mk 4:35-41). The story of the healing of the demon-possessed man and the expulsion from the region of the Gerasenes (Mk 5:1-20) gives no indication that Jesus had slept or had had any rest. Consequently, his willingness to accompany Jairus despite any hunger or tiredness on his part is commendable. Jesus recognises the urgency of Jairus' request.

86. The Acts of Pilate (chapter 7) records a testimony at Jesus' trial in which a woman named Bernice cries out that she had an issue of blood for twelve years and was healed by touching the hem of his garment. The trial leaders respond that 'we have a law not to permit a woman to give testimony' (cf. Levine 2001:74).

87.This section concentrates on the character traits Jesus exhibits in the two encounters.

88. Mathew notes Jesus' capacity for anger. In the earlier Marcan story of Jesus healing the leper (Mk 1:40-45), Mathew (2000:103-104) favours a reading of being angry (orgistheis) rather than being filled with compassion (splagchunisthesis) (v. 41) for it confirms his view that Jesus expresses anger at regarding the existing purity system that excludes categories of people. The reading of being angry comes only in 'a few Old Latin MSS and Ephraem,' he (ibid:103) adds.

89.Power leaves Jesus when he heals. Miller (2004:66) says he heals by the Holy Spirit's power. 
The text shows that in both stories, Jesus accepts worship, and accepts it graciously. Jairus and the woman fall at his feet (vv. 22, 33) and Jesus treats this unusual action as normal. Significantly, he does not reprimand either supplicant. ${ }^{90}$

In the two stories, Jesus accepts three interruptions. In response to the first interruption (Jairus' request), Jesus changes his schedule to meet an immediate need. He agrees to go to Jairus' home. ${ }^{91}$ In response to the second interruption (the woman's touch), Jesus stops. ${ }^{92}$ Jesus asks a question: 'Who touched my clothes?' He knows power left him. ${ }^{93} \mathrm{He}$ ignores the crowd's ridicule and his disciples' incredulity. ${ }^{94}$ Looking specifically for a woman who touched him, he distinguishes between the touch of a woman and the touch of a man. ${ }^{95}$ Notice the irony: Jesus is comfortable with making what seems for the moment to be an absurd statement. ${ }^{96}$ In a crowded, chaotic, urgent situation, he ignores the disciples' character slights and the onlookers' rudeness. Shortly thereafter he tells the professional mourners the child is not dead, but asleep..$^{97}$ Again ridiculed, he refrains from argument. Negative emotions hurled his way do not wound him. These character traits show self-confidence.

In the third interruption - when the messengers come to find Jairus and announce abruptly, even rudely, the death of his daughter - Jesus ignores the messengers' words. He directs his response to Jairus. Jesus quickly orders him not to fear ${ }^{98}$ and instead to believe. ${ }^{99}$ The command means to stop thinking fearful thoughts, and to choose to believe Jesus' original agreement to come and lay hands on the girl. Jairus watched Jesus' interchange with the woman, perhaps

90.This is the traditional position of both worship and homage.

91.Jairus and the demoniac ( $\mathrm{Mk}$ 5:1-20) have something in common: Mark uses the verb parakaleo [I beg of you, please] to describe and summarise their initial encounters with Jesus (Mk 5:10, 23).

92.Edwards (1989:204) points out that the 'woman's interruption, has, of course worked to Jairus' disadvantage, for in the meantime his daughter has died'.

93.Mark 5:30 brings a Greek wordplay into effect by indicating Jesus also knew (epiginosko) that virtue had gone out of him. He has a personal knowledge that power has left him. The verb's prefix, epi, draws attention to the knowledge, thereby intensifying it (Wuest 1966:111).

94.These responses provide a clue for the setting: a thoroughfare too narrow for many people to pass through without touching each other.

95.Mark 5:32 in the King James Version (KJV) states: 'And he looked round about to see her that had done this thing' (italics added) and in the New International Version (NIV) states: 'But Jesus kept looking around to see who had done it'. The Greek favours the KJV. See Aland (1985:126) for an informative, parallel look at the pericope in the Synoptics.

96.During the second interruption, the disciples express incredulity. Why would Jesus stop and demand who touched him?, they ask. Their question showcases again the loneliness of Jesus in Mark, and how he experiences constant misunderstanding rom his closest friends. Wuest's (1966.112) comments are worth noting: 'The disciples were surprised at the sensitivents They were unconscious of the tremendous drain on our Lord from all this healing that tugged away at the tender heart and exhausted the nervous energies of the Son of Man even though He was the Son of God.'

97.When the group, consisting of Jairus, Jesus, the disciples, messengers and the crowd, comes to Jairus' house, the sound of wailing (alalazo) is heard. The Greek word comes from alala, a word denoting the droning, repetitious cry of hired mourners (Wuest 1966:115).

98.Wuest (1966:114) translates: 'The ruler was fearing. Jesus said, "Stop fearing."'

99.Gaiser (2010:9) asks: 'Believe what?' and correctly points out that Jesus and the story do not directly specify what to believe. The implications, however, of belief include include salvation and resurrection and 'suggest a faith in Jesus as Messiah and savior. He (2010.9) also notes that 'faith and healing seem always to be related in the New Testament, but how they relate seems differen "well" (wich case'. For instance, "the hemorrhaging woman is pronounced "well" (which Jairus had requested for his daughter), whilst Jairus's daughter is given new life and participation in the resurrection'. impatiently. He heard her commended for her faith. Perhaps he related Jesus' words to himself (Edwards 1989:204). Jesus' command directs Jairus to choose to concentrate on Jairus' initial, faith-filled statement (v. 23b): 'Please come and put your hands on her so that she will be healed and live.' Jesus gives Jairus a way to direct the incredible energy his emotions as a loving father generate. Succinctly, Jesus commands Jairus to exercise a sustained faith for the girl's healing, even though she is dead. This is an amazing command. Jairus, to his credit, obeys.

Jesus, in addition to showing his ability and right to command, listens. The text shows that Jesus listens first to Jairus and then to the woman without interrupting - a trait showing his good manners. His listening attitude indicates he understands what a person says and the emotions behind the words. Jesus' good manners invite confession; his silence seems to encourage the woman to speak. Jesus welcomes the woman. She seems to gain confidence as she speaks. Arguably, Jesus graciously receives the woman's confession. Indeed, Jesus displays kindness in word and deed throughout the pericope - toward Jairus, the woman and Jairus' family. When the astonished parents see ${ }^{100}$ their beloved daughter walking around the room, Jesus arguably dissolves a tense, tearful situation by telling them to get her something to eat. Perhaps everybody released tension by laughing for joy - Jesus recognizes that a young woman who has recovered from an illness is hungry! Indeed, his kindness, humour and good manners bridge awkward social situations. Consequently, people throughout Mark look to him for leadership and listen to him.

Jesus' actions show an egalitarian nature. ${ }^{101} \mathrm{He}$ heals the powerful and poor; he heals those others may consider 'nobodies', a marginalised, unnamed woman and an unnamed girl. ${ }^{102}$ Jesus recognises normal emotions in crisis situations. The woman comes forward in fear and trembling, and Jairus fears the death of his daughter, the text reveals. However, Jesus accepts trembling and respects courage, but rebukes fear, unbelief and unwarranted mourning. From a canonical perspective, he harkens to the cries of the small and the great, for they constitute faith (cf. Dt 1:17; Ps 115:13).

In a larger sense, Jesus identifies himself with the ill woman and with the dying and dead child. With the latter, he shows he is more powerful than death, for death obeys him. With the former, he leaks power, as one scholar says, just as she leaks blood. ${ }^{103}$

100.The girl gets up and continues to walk about (peripateo in the imperfect indicates 'a repeated condition'). One can easily imagine her going to her mother and father and embracing them. Suddenly she sees four strange men in her bedroom. She learns what has happened to her. Her attention rivets on Jesus. They exchange smiles. Arguably the sickroom contains a kaleidoscope of emotions: grief, hope, wonder, joy, thankfulness, amazement.

101.See the sermon by Willson (2012).

102.The messengers bluntly, without comforting words, tell Jairus his daughter is dead and say (v. 35): 'Why bother the teacher anymore?.'

103.See Moss (2010:507-519) for fascinating insights on how the leakage of blood and the leakage of power connect the Savior and this unnamed woman. Moss (ibid:519) argues that the woman's healing 'underscores his porous femininity'. 
Central to Jesus' character is both his ability to command and his expectation of being obeyed. The text shows that he expects the woman to go away in peace, Jairus to refuse to fear, and the little girl to get up when he speaks to her. ${ }^{104}$ Jesus consistently acts courageously and recognises the courage of the woman in seeking healing and the courage of Jairus in coming to him. ${ }^{105}$ Jesus does not 'fail' in either situation.

His action of listening to a woman goes against established protocol, for a rabbi is warned repeatedly not to talk to a woman in public - not even to his wife (cf. Epstein 1939:Berakot 34b). But Jesus not only listens to this woman, he also compliments her. His words and demeanour praise her pushy actions and her persistence. He rewards her stealth with healing and names it faith. He restores the woman to standing in the community. Jesus places her in a new family, one based on himself. Howbeit indirectly and unplanned by him, Jesus heals the woman. ${ }^{106}$ This shows Jesus' flexibility; evidently all healing does not have to be initiated by him or involve a face-to-face encounter. He gives the woman public honour in place of public embarrassment and shame. People recognise Jesus' ability to bless; Jesus has power to multiply blessings upon the woman. ${ }^{107}$ And he does.

The woman's story brings out yet another aspect of Jesus' character: honesty. Jesus receives the honour she gives him, responds to her homage and accepts her confession. He recognises her actions - actions that amount to a testimony of need combined with what he identifies as faith. Willing to receive public reprimand in order to recognise a woman and acknowledge her need, courage and faith, Jesus demonstrates a courageous and unexpected love toward a lonely, anonymous, desperate woman. ${ }^{108}$

\section{Textual results of the woman's healing}

The woman's story bears similarities with upcoming ones in Mark. Arguably, the people of Gennesaret and Jericho hear about her healing. After all, crowds follow Jesus, he does many miracles in public, and people talk. For instance, Mark 6

104.Mark 5:42 indicates the strength and purposefulness of Jesus' touch. Having taken a strong grip on the hand of the little girl, he says to her 'Talkitha koum', which being interpreted is 'Little girl, to you I say, be arising' (Wuest 1966:117).

105.John F. Kennedy analysed courage in his Pulitzer prize-winning work, Profiles in Courage (1956). Taking Kennedy's (ibid:4-12) insights on the pressures senators face, I apply them to Jesus in Mark. Firstly, senators want to be liked and do things to ensure they are liked. Jesus gradually becomes so disliked and hated that many conspire to kill him. Praise for his actions turns to mockery and contempt. Secondly, senators think in advance; they think about the next election for, Secondly, senators think in advance; they think about the next election for,
after all, many citizens depend upon them. Jesus faces this pressure by telling after all, many citizens depend upon them. Jesus faces this pressure by telling
his disciples of his upcoming death. Thirdly, senators face interest groups. Jesus his disciples of his upcoming death. Thirdly, senators face interest groups. Jesus addresses this pressure by disappointing the interest groups that wanted to
make him king. In Mark, Jesus knows he is gradually becoming more and more unpopular, yet continues teaching, healing and living an exemplary life.

106. Mark 5:29: The woman felt in her body that the flow of blood stopped. The verb ginosoko indicates she indeed knew by experience that the bleeding ceased.

107.Jesus' benediction of peace, in Hebrew shalom, indicates well-being, salvation, prosperity and health of body, soul, mind and spirit. Jesus blesses her with a prophetic word about her restored life: it will be complete, finished, peaceful, full of friendship, health, kindness, prosperity and even luck and salvation (Van Gemeren 1997:IV.130). Jesus' blessing, given in the present imperative ('be whole of thy plague') also speaks to the woman's natural fear of a sudden or gradual return of her condition. A good translation of Jesus' blessing comes from Wuest (1966:114): 'Daughter, your faith has saved you. Be going in peace. Be continually (1966:114): 'Daughter, your faith has saved you.
sound in body from your affliction' (Mk 5:34).

108.See Bailey (2008:259) for his views on a similarly desperate woman in the house of Simon the Pharisee (Lk 7:36-50). opens with Jesus and his disciples going to his hometown and ends with his return to Gennesaret (Mk 6:53-56). Verse 56 describes how the sick in the marketplaces begged Jesus 'to let them touch even the edge of his cloak, and all who touched him were healed'. A difference in the stories of the woman and the people of Gennesaret is that the latter asks permission to touch his cloak.

Secondly, like the woman, blind Bartimaeus of Jericho is healed (Mk 10:46-52) ${ }^{109}$ Bartimaeus and the woman share persistence as a trait. Each desperately needs healing, knows the sting of public ostracism, has heard of Jesus, and seeks Jesus. ${ }^{110}$ Each persists in overcoming obstacles in getting to Jesus. The woman keeps moving amongst the jostling crowd to get in position to touch his garment; Bartimaeus keeps shouting (Mk 10:47): 'Jesus, Son of David, have mercy on me!'; heedless of public ostracism. Jesus responds to a desperate action and to a cry of need the same way. Jesus heals both and graciously commends each with the same words by saying: 'your faith has healed you' (Mk 5:34; 10:52). Jesus shares the credit, honour and responsibility of the healing with the woman and Bartimaeus. This sharing shows yet another character trait: his gracious nature.

\section{How the story of the woman contributes to ongoing themes in Mark}

A careful textual reading about the woman in the crowd reveals her courage, eloquence, stealth and desperation all character elements, it turns out, that can be associated with an individual's faith. ${ }^{111}$ The woman enlarges Mark's earlier portrayal of faith in several ways. To begin with, she approaches Jesus from behind, choosing not to initiate a faceto-face encounter. Instead of asking for healing in a nice way, she, in a sense, grabs it. My interpretation of this is that her healing comes without an open request to Jesus and without Jesus' initiative. She seemingly forces him to heal her without his permission. And he does!

Suddenly, he is not in control. In my opinion, her pushiness, her persistence regarding getting herself healed, arguably signals a new way. Her faith activates Jesus' power. Her faith adds to examples of faith already in Mark. Her faith includes energised, determined, self-centred, pushy self-interest; it focuses on Jesus. Self-interest is based on need; focus is based on an analysis of Jesus' character. In the woman's case, she needs healing and knows that the carpenter from Nazareth has healed others. Arguably, Jesus retroactively agrees with her healing because he allows her to keep it.

Consequently, the woman in the crowd both enlarges prevailing theology and pushes past it. ${ }^{112}$ The prevailing

109.Robbins (1973:224) notes the realism of Bartimaeus' story.

110.Achtemeier (1978:115) notes the persistence of Bartimaeus and the blindness of the disciples.

111.The woman's story forms the basis of the opening scene from the novel The Wonder Worker by Susan Howatch (1997).

112. The biblical text presents progressive theology. Everything about God is not known in Genesis 1:1. The Bible presents a progressive revelation of the character of God (cf. Walton \& Hill 2004:4, 6). For example, a reason why the psalms are in Scripture is that they portray God's character accurately (Walton \& Hill ibid:361). 
theology so far in Mark is that Jesus graciously heals, but that healing must come via a face-to-face encounter with him and must be with Jesus' agreement. The woman's planned action of coming from behind demonstrates that faith pulls power from him. Indeed, the woman's actions show deliberation and planning. Whilst this faith approach is unusual, Mark presents it as allowable (Powell 2005:74). ${ }^{113}$

Garland (2002:36) links the miracle the woman experienced - the stopping of her blood flow - with the resurrection of Jesus. In the resurrection, the forces of death are held at bay via faith (Garland ibid:36). So in a broad sense, the woman in the crowd points to the crucifixion (Mk 15:21-41; cf. Miller 2004:66). Her stigma of flowing blood points to the stigma of the cross that Jesus will soon bear (cf. Miller ibid:65).The disease that afflicts her is portrayed as evil; she suffers from it. Likewise, Jesus will suffer at the hands of evildoers. Her story illustrates that those who respond to Jesus are not exempt from suffering, chaos, persecution and the vicissitudes of the world - clearly a central teaching in Mark.

The woman also is portrayed as a successful disciple, and one much more successful than the twelve male disciples at this point in the gospel of Mark. How is this so? Firstly, she models the kind of discipleship Jesus preaches: persistence, risk-taking, suffering, confession and overcoming fear. The woman serves as a model of faith. She responds to Jesus' message in a more positive way than his closest associates do who are still stinging from Jesus' rebuke to them in the boat (Mk 4:40). Secondly, she believes what she hears about Jesus and applies it to herself, believing she can be healed. Thirdly, like the male disciples, she follows Jesus, but in a way tailored to her.

Her life and story serve as an encouragement to the community to whom Mark writes (Miller 2004:67). A part of her story that well may serve as a model for others is public confession: falling at his feet is an act of worship. The healing of the woman in the crowd and the raising from death of Jairus' daughter illustrate Jesus' open engagement in battle with disease and death. His presence, touch, and direct command overcome both. ${ }^{114}$ The combined stories of the woman in the crowd and the raising of Jairus' daughter are evidence that a new world order has come. A new creation breaks through because of these and other events in Mark's gospel.

Significantly, Jesus does not reprimand her for touching him or for mingling with the crowd. This lack of rebuke serves to shatter the prevailing system of legal purity and its restraints on social interactions (Selvidge 1984:622).

\section{Conclusion}

An encounter with Jesus changes a person. Mark provides ample evidence of this. The woman's initial condition of

113.The story of the raising of Jairus' daughter 'emphasizes Jesus' power and deity, Powell (2005:75) says.

114.Miller (2004:72) notes that the healing of the woman and Jairus' daughter 'foreshadows the abundance of the kingdom of God, which breaks into the world in the midst of human suffering'. extreme need is not the concluding word on her life. Instead of dying, she lives. Instead of the ebbing away of her life force, she receives new energy and new life. Her hopelessness and desperation drive her to plan a sneaky, one-sided encounter with Jesus. Her plan fails, however, for she does not consider this: Jesus knows when power leaves him. Jesus searches for her - the one in the crowd who pulled power from him.

She comes forward and confesses. Instead of rendering a reprimand, Jesus acknowledges her action, for it took courage and expressed what he succinctly calls faith. Jesus is the focus of her faith, and of her determination, courage, desperation, need and self-interest. His healing of her affliction restores her to the covenant community. By calling her Daughter, he rewards her with public praise. He assures her of ongoing healing and of a prominent position in his new family; his gracious dismissal acknowledges her wholeness. In the finest sense, the unnamed woman in the crowd is a biblical heroine. Significantly, she - now whole, clean, set in a new family, and a recognised follower of Jesus - arguably grasps what the crowd and the Twelve are, so far at least, so slow to acknowledge: he is indeed the Son of God (Mk 1:1).

\section{Acknowledgments Competing interests}

The author declares that she has no financial or personal relationship(s) that may have inappropriately influenced her in writing this article.

\section{References}

Achtemeier, P.J., 1978, '"And He Followed Him": Miracles and Discipleship in Mark 10:46-52', Semeia 11, 115-145.

Ahearne-Kroll, S.P., 2001, “'Who are my mother and my brothers?" Family relations and family language in the gospel of Mark', Journal of Religion 81(1), 1-25. http:// dx.doi.org/10.1086/490763

Aland, K. (ed.), 1985, Synopsis of the Four Gospels, English edn., American Bible Society, New York.

Barclay, W., 1956, The Gospel of Mark, The Westminster Press, Philadelphia.

Bailey, K.E., 2008, Jesus through Middle Eastern eyes: Cultural studies in the gospels, InterVarsity Press, Downers Grove.

Betz, H.D., 1978, 'The early Christian miracle story: Some observations on the form critical problem', Semeia 11(1), 69-81.

Blount, B.K. \& Charles, G.W., 2002, Preaching Mark in two voices, Westminster John Knox Press, Louisville.

Boring, M.E. \& Craddock, F.B., 2004, The people's New Testament commentary, Westminster/John Knox Press, Louisville.

Bouquet, A.C., 1953, Everyday life in New Testament times, Charles Scribner's Sons, New York.

Branch, R.G.,2003, 'Evangelism via power and lifestyle: Elijah's method in 1 Kings 17', Missionalia 31(2), 293-304.

Branch, R.G., 2007, 'Barnabas: A model of ethical encouragement', In die Skriflig 41(2), 295-322.

Branch, R.G., 2009, Jeroboam's wife: The enduring contributions of the Old Testament's least-known women, Hendrickson Publishers, Peabody.

Calvin, J., 1981, Commentary on harmony of the evangelists, Matthew, Mark and Luke, vol. 1, transl. W. Pringle, Baker Book House, Grand Rapids.

Cotter, W., 2001, 'Mark's hero of the twelfth-year miracles: The healing of the woman with the hemorrhage and the raising of Jairus' daughter', in A-J. Levine \& M. Blickenstaff (eds.), A Feminist Companion to Mark, pp. 54-78, Sheffield Academic Press, Sheffield.

Darden, R., 2006, Reluctant prophets and clueless disciples: Introducing the Bible by telling its stories, Abingdon, Nashville.

Deen, E., 1955, All the women of the Bible, Harper \& Row, New York.

Edwards, J.R., 1989, 'Markan sandwiches: The significance of interpolations in Markan narratives', Novum Testamentum 31(3), 193-216. 
English, D., 1992, The message of Mark: The mystery of faith, InterVarsity Press, Downers Grove.

Epstein, I. (ed.), 1939, Babylonian Talmud, Soncino, Jerusalem.

Eusebius, 2007, Eusebius: The church history, transl. P.L. Maier, Kregel Academic and Professional, Grand Rapids.

Foster, R.J., 1998, Celebration of discipline: The path to spiritual growth, HarperSanFrancisco, New York.

Freedman, D.N., Myers, A.C. \& Beck, A.B (ed.), 2000, Eerdmans Dictionary of the Bible, Eerdmans, Grand Rapids. http://dx.doi.org/10.5117/9789053565032

Gaiser, F.J., 2010, 'In touch with Jesus: Healing in Mark 5:21-43', Word \& World 30(1), 5-15.

Gane, R.E., 2009, 'Leviticus', in J.H. Walton (gen. ed.), Zondervan Illustrated Bible Backgrounds Commentary, pp. 284-337, Zondervan, Grand Rapids.

Garland, D.E., 1996, The NIV application commentary: Mark, Zondervan, Grand Rapids.

Garland, D.E., 2002, Mark, Zondervan, Grand Rapids.

Guelich, R.A., 1989, Word Biblical Commentary Volume 34A: Mark 1-8:26, Word Books Publisher, Dallas.

Haber, S., 2003, 'A woman's touch: Feminist encounters with the hemorrhaging woman in Mark 5:24-34', Journal for the Study of the New Testament 26(2), 171192. http://dx.doi.org/10.1177/0142064X0302600203 Hay, E.R., 1973, 'What is the nature of faith in faith-healing?', Perkins Journal 26(3),
17-23.

Hedrick, C.W., 2007, 'Miracles in Mark: A study in Markan theology and its implications for modern religious thought', Perspectives in Religious Studies 2007 (3), 29-313.

Hiebert, D.E., 1979, Mark: A portrait of the servant, Moody Press, Chicago.

Hill, A.E. \& Walton, J.H., 2000, A survey of the Old Testament, Zondervan, Grand Rapids.

Howatch, S., 1997, The wonder worker, Fawcett Columbine, New York.

Johnson, E.S. Jr., 1978, 'Mark 10:46-52: Blind Bartimaeus', The Catholic Biblical Quarterly 40(2), 191-204.

Josephus, 2007, The works of Josephus, transl. W. Whiston, Hendrickson Publishers, Peabody.

Kennedy, J.F., 1956, Profiles in courage, Harper \& Brothers Publishers, New York.

Levine, A-J., 2001, 'Discharging responsibility: Matthean theology, Biblical law, and hemorrhaging woman', in A-J.Levine and M. Blickenstaff (eds.), A feminist companion to Matthew, pp. 70-87, Sheffield University Press, Sheffield.

Loader, W., 2007, The New Testament with imagination: A fresh approach to its writings and themes, Eerdmans, Grand Rapids.

Lockyer, H., 1965, All the miracles of the Bible, Zondervan, Grand Rapids.

Lostracco, J. \& Wilkerson, G., 2008, Analyzing short stories, 7th edn., Kendall/Hunt Publishing Company, Dubuque.

Mack, B.L., 1988, A myth of innocence: Mark and Christian origins, Fortress Press, Philadelphia.

Mann, C.S., 1986, Mark: A new translation with introduction and commentary, Doubleday, New York.

Matera, F.J., 1987, What are they saying about Mark?, Paulist Press, New York.

Mathew, S.P., 2000, 'Jesus and purity system in Mark's gospel: A leper (Mk. 1:40-45)', Indian Journal of Theology 42(2), 101-110.

Mathews, A., 1998, A woman God can lead: Lessons from women of the Bible help you make today's choices, Discovery House Publishers, Grand Rapids.

Miller, S., 2004, Women in Mark's gospel, T\&T Clark International, London.

Miller, M.S. \& Miller, J.L., 1978, Harper's Encyclopedia of Bible life, Harper \& Row, New York.

Minear, P.S., 1960, The Gospel according to Mark, John Knox Press, Atlanta.
Minor, M., 2001, The power of Mark's story, Chalice Press, St. Louis.

Moss, C.R., 2010, 'The man with the flow of power: Porous bodies in Mark 5:25-34', Journal of Biblical Literature 129(3), 507-519.

Murphy, F.J., 2005, An introduction to Jesus and the gospels, Abingdon Press, Nashville.

National Heart, Lung and Blood Institute, 2011, What is Iron-Deficiency Anemia?, viewed 13 January 2011, from http://www.nhlbi.nih.gov/health/dci/Diseases/ ida/ida_signsandsymptoms.html.

NIV Study Bible, 1995, Zondervan, Grand Rapids.

Ogilvie, L.J., 1975, Life without limits: The message of Mark's gospel, Word Books, Waco.

Osborn, T.L., 1981, Healing the sick: A living classic, Harrison House, Tulsa.

Packer, J.I., \& M.C. Tenney (eds.), 1980, Illustrated manners and customs of the Bible, Thomas Nelson Publishers, Nashville.

Peacock, H.F., 1978, 'Discipleship in the Gospel of Mark', Review \& Expositor 75(4), 555-564.

Powell, C.E., 2005, 'The "Passivity" of Jesus in Mark 5:25-34', Bibliotheca Sacra 162(1), 66-75.

Pratt, R.L. Jr. (gen. ed.), 2003, 'Westminster confession of faith', in Spirit of the Reformation Study Bible, pp. 2175-2189, Zondervan, Grand Rapids.

Robbins, V.K., 1973, 'The healing of blind Bartimaeus (10:46-52) in the Marcan theology', Journal of Biblical Literature 92(2), 224-243. http://dx.doi. org/10.2307/3262955

Rhoads, D., 2004, Reading Mark:Engaging the Gospel, Fortress Press, Minneapolis.

Ross, A.P., 2002, Holiness to the Lord: A guide to the exposition of the book of Leviticus, Baker Academic, Grand Rapids.

Schnittjer, G.E., 2006, The Torah Story, Zondervan, Grand Rapids.

Schweizer, E., 1978, 'The portrayal of the life of faith in the gospel of Mark', Interpretation 32(4), 387-399. http://dx.doi.org/10.1177/002096437803200404

Selvidge, M.J., 1984, 'Mark 5:25-34 and Leviticus 15:19-20: A reaction to restrictive purity regulations', Journal of Biblical Literature 103(4), 619-623. http://dx.doi. org/10.2307/3260473

Sherwood, S.K., 2002, Leviticus, Numbers, Deuteronomy. Berit Olam: Studies in Hebrew Narrative \& Poetry, The Liturgical Press, Collegeville.

Spencer, F.S., 2010, 'Faith on edge: The difficult case of the spirit-seized boy in Mark 9:14-29', Review and Expositor 107(Summer), 419-424.

Spurgeon, C.H., 1959, Women of the New Testament, Zondervan, Grand Rapids.

Swanson, R.W., 2011, 'Moving bodies and translating Scripture: Interpretation and incarnation', Word \& World 31(3), 271-278.

Thurston, H. \& Attwater, D. (eds.), 1956, Butler's lives of the Saints, vol. 1-4, P.J. Kenedy \& Sons, New York.

Tolbert, M.A., 1992, 'Mark', in C.A. Newsom \& S.H. Ringe (eds.), The Women's Bible Commentary, pp. 263-274, Westminster John Knox Press, Louisville.

Van Gemeren, W.A. (ed.), 1997, New International Dictionary of Old Testament Theology and Exegesis, vol. I-V, Zondervan, Grand Rapids.

Wenham, G.J., 2003, Exploring the Old Testament: A guide to the Pentateuch, InterVarsity Press, Downers Grove.

Wall, L.L., 2010, 'Jesus and the unclean woman. How a story in Mark's gospel sheds light on the problem of obstetric fistula', Christianity Today January, 48-52.

Walton, J.H \& Hill, A.E., 2004, Old Testament today: A journey from original meaning to contemporary significance, Zondervan, Grand Rapids.

Williamson, L. Jr., 1983, Interpretation. A Bible commentary for teaching and preaching: Mark, John Knox Press, Louisville.

Willson, S.L., 2012, 'Talitha Cumi', sermon delivered at Second Presbyterian Church, Memphis, 13 May.

Wuest, K.S., 1966, Wuest's word studies from the Greek New Testament for the English reader, vol. 1, Eerdmans, Grand Rapids. 